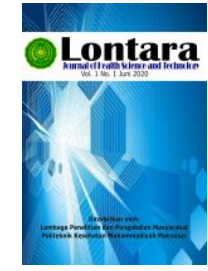

Lontara

Journal of Health Science and Technology

http://jurnal.poltekkesmu.online/lontarariset

Vol 2, No. 1, Juni 2021, pp 31-34

p-ISSN:0000-0000 dan e-ISSN: 2721-6179

DOI:https://doi.org/

\title{
ANALISA ARTEFAK PADA HASIL RADIOGRAF YANG TIMBUL AKIBAT PENGOLAHAN COMPUTED RADIOGRAPHY
}

\author{
Wahyuddin, A. AR. Rakhmansyah, Nurul Adilah Z.
}

Program Studi Radiologi, Politeknik Kesehatan Muhammadiyah Makassar

Email: wahyuddin@poltekkesmu.ac.id

\section{Artikel info}

\section{Artikel history:}

Received;03-03-2021

Revised:22-05-2021

Accepted;24-05-2021

\section{Keyword:}

Cause Of Artifacts, The

Fault of Processing

Film, $\quad$ Computed

Radiography.

\section{Kata Kunci:}

Penyebab

Kesalahan

Film,

Pengolahan

Radiography.
Abstract. Artefacts are structures or appearances that are not normally present on radiographs, errors in radiographic processing may be due to technical errors or film processing errors. This research was conducted using Descriptive methods, with the type of literature study that aims to examine the causes of artifacts that can occur as a result of improper handling of film processing errors.The results of the analysis concluded that the frequent occurrence of artifacts in the processing of Computed Radiography is caused by two factors, that is the use of imaging plates and grids lisolm. His advice should be in the processing using Computed Radigraphy the officer must be more careful and pay attention to the components in Computed Radiography.

Abstrak. Artefak adalah struktur atau penampilan yang tidak biasanya hadir pada radiografi, kesalahan dalam pengolahan radiografi mungkin disebabkan karena kesalahan teknis atau kesalahan pengolahan film. Penelitian ini dilakukan dengan menggunakan metode deskriptif, dengan jenis penelitian studi literatur yang bertujuan untuk mengkaji tentang penyebab artefak yang dapat terjadi akibat dari penanganan yang tidak tepat dari kesalahan pengolahan film. Hasil analisis menyimpulkan bahwa seringnya terjadi artefak pada proses pengolahan Computed Radiography disebabkan oleh dua faktor yaitu penggunaan imaging plate dengan grid lisolm. Sarannya sebaiknya dalam proses pengolahan menggunakan Computed Radiography petugas harus lebih teliti dan memperhatikan komponen-komponen pada Computed Radiography

Coresponden author:

Email: wahyuddin@poltekkesmu.ac.id

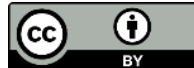

artikel dengan akses terbuka dibawah lisensi CC BY -4.0 


\section{PENDAHULUAN}

Radiografi komputer (Computed Radiography) menggantikan pemrosesan gambar sinar-X dari radiologi konvensional dengan menghasilkan gambar radiografi digital berkualitas tinggi secara konsisten. Radiografi komputer dapat digunakan dalam berbagai prosedur diagnostik di fasilitas radiologi konvensional, khususnya dapat meningkatkan kualitas gambar, mengurangi duplikasi dan menolak film, karena radiografi komputer dapat memproses hasil gambar radiografi sebelum dicetak atau disalin dalam bentuk hard copy. Radiografi berkualitas tinggi dapat diproduksi dalam waktu singkat dan dapat memberikan informasi diagnostik terbaik untuk pembelajaran.

Artefak adalah struktur atau penampakan yang biasanya tidak tampak pada radiografi.Kesalahan dalam pemrosesan radiografi dapat disebabkan oleh kesalahan teknis atau kesalahan pemrosesan film. Karena penanganan transportasi film yang tidak tepat, pemrosesan film yang tidak disengaja, dan cacat pada kemasan transportasi film, dapat menyebabkan artefak. Selain itu, pergerakan tabung, kepala pasien, atau film yang berlebihan dapat menyebabkan berbagai cacat pada radiografi biasa.

\section{METODE PENELITIAN}

Penelitian ini bertujuan untuk mengetahui bagaimana cara menganalisa artefak yang muncul akibat pengolahan film CR. Jenis penelitian yang digunakan ialah penelitian deskriptif melalui studi literatur yang sesuai.

\section{HASIL PENELITIAN}

\begin{tabular}{|l|l|l|l|l|}
\hline NO & $\begin{array}{l}\text { Nama Jurnal / No. } \\
\text { Volume/ } \\
\text { Tahun/Penulisan }\end{array}$ & Judul Penelitian & $\begin{array}{l}\text { Desain } \\
\text { Penelitian }\end{array}$ & Hasil Penelitian \\
\hline 1 & $\begin{array}{l}\text { Jurnal Ilmu dan } \\
\text { Teknologi Kesehatan/ } \\
\text { Volume 9, No 2/ } \\
\text { Februari 2018 (ISSN } \\
\text { 2086-8510) / } \\
\text { Ayu Wita Sari, Fadly }\end{array}$ & $\begin{array}{l}\text { Faktor Terjadinya } \\
\text { Penyebab Artefak } \\
\text { Pada Hasil } \\
\text { Radiograf } \\
\text { Computed } \\
\text { Radiography di } \\
\text { RSUP dr. Soeradji } \\
\text { Tirtonegoro Klaten }\end{array}$ & $\begin{array}{l}\text { Kualitatif } \\
\text { Deskriptif }\end{array}$ & $\begin{array}{l}\text { Hasil Penelitian } \\
\text { Menunjukkan Bahwa } \\
\text { Penyebab Terbesar } \\
\text { Terjadinya Artefak Yaitu } \\
\text { di Timbulkan Oleh } \\
\text { Imaging Plate dan } \\
\text { Penggunaan Grid }\end{array}$ \\
\hline 2 & $\begin{array}{l}\text { Jurnal Riset Kesehatan// } \\
\text { Volume 6, No } \\
\text { 2 Februari } \\
\text { 2017 (ISSN: } \\
\text { 2252-5068 e- } \\
\text { ISSN: 2461- } \\
\text { 1026) / Dwi } \\
\text { Rochmayanti, Darmini, } \\
\text { Marichatul } \\
\text { Jannah }\end{array}$ & $\begin{array}{l}\text { Kolimasi, Ukuran } \\
\text { Imaging Plate dan } \\
\text { Delay Time } \\
\text { Processing } \\
\text { Terhadap } \\
\text { Exposure Index }\end{array}$ & $\begin{array}{l}\text { Kuantitatif } \\
\text { Experiment }\end{array}$ & $\begin{array}{l}\text { Penyebab artefak dapat di } \\
\text { timbulkan oleh kesalahan } \\
\text { penggunaan image plate. } \\
\text { Kondisi imaging plate juga } \\
\text { dicek dan dilakukan } \\
\text { erasing sebelum digunakan } \\
\text { untuk meminimalkan } \\
\text { adanya artefak yang } \\
\text { mungkin ditimbulkan } \\
\text { akibat tidak digunakannya } \\
\text { imaging plate dalam waktu } \\
\text { yang cukup lama. }\end{array}$ \\
\hline
\end{tabular}


Analisa Artefak Pada Hasil Radiograf Yang Timbul Akibat Pengolahan Computed Radiography

(Wahyuddin, A. AR. Rakhmansyah, Nurul Adilah Z)

\begin{tabular}{|c|c|c|c|c|}
\hline 3 & $\begin{array}{l}\text { Jurnal LINK/ Volume } \\
\text { 12, No } \\
\text { 1 Januari 2016 } \\
\text { (ISSN: 1829- } \\
\text { 5754 e-ISSN: } \\
\text { 2461-1077) / } \\
\text { Dwi Rochmayanti, Jeffri } \\
\text { Ardiyanto, Ardi Soesilo } \\
\text { Wibowo }\end{array}$ & $\begin{array}{l}\text { Pelatihan } \\
\text { Pengaturan Indeks } \\
\text { Eksposure Untuk } \\
\text { Optimasi Kualitas } \\
\text { Radiograf dan } \\
\text { Estimasi Dosis } \\
\text { Pada Computed } \\
\text { Radiography } \\
\text { Kodak }\end{array}$ & $\begin{array}{l}\text { In House } \\
\text { Training }\end{array}$ & $\begin{array}{l}\text { Meningkatkan } \\
\text { Kemampuan Radiografer } \\
\text { Dalam Memaksimalkan } \\
\text { Modalitas Computer } \\
\text { Radiografi Untuk Berdaya } \\
\text { Guna dan Mendukung } \\
\text { Dalam Menghasilkan } \\
\text { Sebuah Citra Radiografi } \\
\text { Yang Memiliki Kualitas } \\
\text { Gambar Optimal. }\end{array}$ \\
\hline 4 & $\begin{array}{l}\text { Jurnal Fisika } \\
\text { Indonesia/ Volume 17, } \\
\text { No 50 Agustus 2013 } \\
\text { (ISSN:2579-8820) } \\
\text { /Susilo, Sunarno, Ketut } \\
\text { Swakarma }\end{array}$ & $\begin{array}{l}\text { Kajian Sistem } \\
\text { Radiography } \\
\text { Digital Sebagai } \\
\text { Sistem Computed } \\
\text { Radiography Yang } \\
\text { Mahal }\end{array}$ & Experiment & $\begin{array}{l}\text { Hasil Yang Diperoleh } \\
\text { Adalah Radiograf } \\
\text { Dengan Warna Kehijauan, } \\
\text { Resolusi dan Detailnya } \\
\text { Masih Kurang, Ini Tak } \\
\text { Sesuai Dengan Warna } \\
\text { Keluaran Radiograf Pada } \\
\text { Sistem CR. }\end{array}$ \\
\hline
\end{tabular}

\section{PEMBAHASAN}

Menurut jurnal yang diperoleh berkaitan dengan faktor penyebab terjadinya artefak dan penyebab terbesar terjadinya artefak di Computed Radiography yaitu:

\section{a. Imaging Plate Artefak}

Jika dilihat dari foto softcopy X-ray dengan persentase abu-abu normal, hal itu terjadi akibat munculnya gambar berupa garis-garis putih pada bagian pinggir foto X-ray. Jika area anatomis tertutup maka hal ini akan menyebabkan artefak pada foto sinar-X. Bayangan biasanya ditemukan pada peralatan radiografi yang menggunakan kaset berukuran $24 \times 30 \mathrm{~cm}$ untuk pemeriksaan. Artefak pelat pencitraan karena seringnya menggunakan pelat gambar kurang terawat, dan pita sering menumpuk dan sering jatuh. Dilihat dari proses pembacaan imaging plate, seringkali plat imaging tersebut tergores, karena jika ingin menscan imaging plate harus mengeluarkannya dari kaset dan membengkokkannya setelah melakukan scanning dan imaging, yang biasanya mengakibatkan tergoresnya imaging plate. Jika digunakan dalam waktu yang lama akan menghasilkan tanda garis pada plat gambar. Goresan ini dapat menyebabkan artefak karena sensitivitas tinggi pelat gambar berpendar.

\section{b. Grid Lisolm Artefak}

Penggunaaan grid lisolm merupakan faktor penyebab artefak pada hasil radiograf artefak ini ditandai dengan adanya moire pattern atau garis-garis yang berpola sejajar artefak ini biasanya di temui pada pemeriksaan yang menggunakan grid lisolm, adanya artefak ini dikarenakan penggunaan dari grid dengan frekuensi garis grid kurang dari 60 lines/cm dalam orientasinya garis grid akan di scan sejajar oleh plate reader scan lines semakin tinggi tingkat garis grid maka akan semakin baik dan tidak akan menimbulkan artefak sebaliknya semakin kurang tingkat garis grid maka akan menimbulkan artefak pada hasil radiografi. 


\section{KESIMPULAN}

Dari hasil penelitian dapat disimpulkan bahwa ada dua alasan sering terjadinya Atefacts dalam pengolahan pencitraan radiografi komputer, yaitu penggunaan imaging plate dan lysolm grids.

\section{SARAN}

Sebaiknya dalam proses pengolahan menggunakan Computed Radiography kita harus teliti dan memperhatikan komponen-komponen Computed Radiography agar menjaganya dan merawat alat tersebut sehingga tidak lagi menimbulkan artefak pada hasil Radiography.

\section{DAFTAR PUSTAKA}

Ballinger, P. W., \& Frank, E. D. (1999). Merrill's atlas of radiographic positions and radiologic procedures. Vol. 3. Mosby.

Bayan, A. (2013,). Komponen-Komponen CR. Retrieved from: http://malfatih8.blogspot.co.id: http://malfatih8.blogspot.co.id

Bontrager, K. L., \& Lampignano, J. P. (2001). Radiographic positioning and related anatomy: workbook and laboratory manual.

Carter, C., \& Veale, B. (2018). Digital radiography and PACS E-Book. Elsevier Health Sciences.

Fauber, T. L. (2016). Radiographic Imaging and Exposure-E-Book. Elsevier Health Sciences.

Iddir, S. (2007). Computed Radiography. Biomedical instrumentation \& technology, 41(2), 141-144.

Sayuti, N., Imbaruddin, A., \& Rusli, R. H. (2015). Mutu Pelayanan Radiologi Pasien Rawat Jalan Di Rumah Sakit Bhayangkara Makassar. Jurnal Administrasi Negara. STIA LAN Makassar, 21(2), 42643.

Strudwick, R. M. (2014). The radiographic image: A cultural artefact?. Radiography, 20(2), 143-147.

Tateno, Y., Iinuma, T., \& Takano, M. (Eds.). (2012). Computed radiography. Springer Science \& Business Media.

Utami, A. P., Saputro, S. D., \& Felayani, F. (2014). Radiologi Dasar I. Inti Medika Pustaka.

Whitley, A. S., Jefferson, G., Holmes, K., Sloane, C., Anderson, C., \& Hoadley, G. (2015). Clark's Positioning in Radiography 13E. crc Press.

Wicke, L. (1987). Atlas of radiologic anatomy. 